\title{
Mengurai Eksistensi Lingkungan Pendidikan Islam Perspektif Sosiologis
}

\section{Murdianto}

Universitas Islam Negeri Mataram

Naskah diterima 14 Nov 2018, direvisi 19 Des 2018, disetujui 26 Jan 2018

Abstract The environment of religious education is a means that can provide motivation, educational facilities, the vehicle of self potential learners development effective-efficient value by development, needs, as well as provide guidance and serious attention to the moral spiritual needs. The article entitled unravel the existence of Sociological perspective of Islamic Educational Environments there are three elements, families, schools, and communities. The third element of the responsibility for progress or setbacks of Islamic education. As well as being a unified whole and complementary and should be able to carry out its function as a means of motivating, educational facilities, the vehicle of potential development.

Keywords: Existence, Islam, sociology, education

Abstrak Lingkungan pendidikan agama merupakan sarana dapat memberikan motivasi, fasilitas edukatif, wahana pengembangan potensi diri peserta didik bernilai efektif-efisien dengan perkembangan, kebutuhan, serta memberikan bimbingan dan perhatian serius terhadap kebutuhan moral-spiritual. Artikel yang berjudul Mengurai Eksistensi Lingkungan Pendidikan Islam Perspektif Sosiologis terdapat tiga unsur yaitu keluarga, sekolah dan masyarakat. Ketiga unsur tersebut bertanggung jawab atas kemajuan ataukemunduranpendidikan Islam. Serta menjadi satu kesatuan yang utuh dan saling melengkapi dan harus mampu melaksanakan fungsinya sebagai sarana yang memberikan motivasi, fasilitas edukatif, wahana pengembangan potensi.

Kata kunci: Eksistensi, Islam, Sosiologi, Pendidikan 


\section{A. PENDAHULUAN}

Dalam persfektif sosiologis lingkungan pendidikan terbagi menjadi tiga lingkungan yaitu; lingkungan keluarga, sekolah dan lingkungan masyarakat. Menurut Hadari Nawawi, ketiga lingkungan tersebut bertanggung jawab atas maju mundurnya pendidikan khususnya pendidikan Islam (Nawawi, 1989:7). Ketiganya merupakan satu kesatuan yang utuh dan saling melengkapi antara yang satu dengan yang lain. Ketiganya harus mampu melaksanakan fungsinya sebagai sarana yang memberikan motivasi, fasilitas edukatif, wahana pengembangan potensi yang ada pada diri peserta didik dan mengarahkannya untuk mampu bernilai efektif-efisien sesuai dengan perkembangan dan kebutuhan zamannya serta memberikan bimbingan dan perhatian yang serius terhadap kebutuhan moral-spiritual peserta didiknya.Bimbingan yang dimaksud meliputi pengembangan potensi anak didik, transformasi ilmu pengetahuan dan kecakapan lainnya, dan membangkitkan motif-motif yang ada secara maksimal (Taufik dan Shiddiqi, 1989: 34-35). Dalam persfektif sosiologis, di samping ketiga unsur tersebut, yang paling bertanggung jawab atas terlaksananya pendidikan Islam adalah manusia sebagai subjek dan objek pendidikan.Tanpa kesadaran dan tumbuhnya nilai tanggung jawab pada dirinya, mustahil pendidikan Islam mampu memainkan peranannya secara optimal.Untuk itu, di samping ketiga unsur di atas, diperlukan kesiapan dan tanggung jawab yang besar pada diri peserta didik sebagai hamba Allah yang siap melaksanakan amanat-Nya di muka bumi.

Beratnya tanggung jawab yang dipikul oleh unsur-unsur di atas dalam upayanya mengantarkan peserta didik muslim kepada tujuan Ilahi yang Agung, menjadikannya sebagai salah satu kekuatan penentu berhasil atau tidaknya pendidikan Islam sebagai pioner pembangunan peradaban umat.Terutama di era modern saat ini. Oleh karenanya, kesemua unsur tersebut harus mampu bergandeng secara padu dan utuh, dengan tanpa melepaskan diri dari roh akidah Islamiah. Kesemua ini menurut 
Islam, secara konsep imani, akan diminta pertanggungjawabannya oleh Allah kelak di akhirat, atas apa yang pernah dilakukan dalam mengantarkan peserta didik ke arah tujuan pendidikan Islam. Dalam hal ini Rasulullah saw bersabda yang artinya: "setiap kamu adalah pemimpin. Dan setiap pemimpin akan diminta pertanggungjawabannya" HR. Muttafaq'a1aih (Fathurrahman, 2007:45).

Hadis tersebut memberikan penjelasan, bahwa yang ikut bertanggung jawab atas terlaksananya pendidikan Islam bukan saja ada pada keluarga, sekolah, masyarakat dan pemerintah saja, tetapi juga menjadi tanggung jawab bagi setiap pribadi muslim.

Artikel ini mengkaji mengenai Sekolah, keluarga dan masyarakat dapat bertanggungjawab atas kemajuan ataukemunduranpendidikan Islam.Serta menjadi satu kesatuan yang utuh dan saling melengkapi dan harus mampu melaksanakan fungsinya sebagai sarana yang memberikan motivasi, fasilitas edukatif, wahana pengembangan potensi. Lingkungan pendidikan agama dapat memberikan motivasi, fasilitas edukatif, wahana pengembangan potensi diri bagi peserta didik bernilai efektifefisien dengan perkembangan, kebutuhan, serta memberikan bimbingan dan perhatian serius terhadap kebutuhan moralspiritual.

\section{B. PEMBAHASAN}

\section{Lingkungan Keluarga}

Secara sosiologis keluarga merupakan lembaga pertama dan utama yang dikenal oleh anak.Hal ini disebabkan, karena kedua orang tuanyalah orang yang pertama dikenal dan diterimanya pendidikan.Bimbingan, perhatian, dan kasih sayang yang terjalin antara kedua orang tua dengan anak-anaknya, merupakan basis yang ampuh bagi pertumbuhan dan perkembangan psikis serta nilai-nilai sosial dan religius pada diri anak didik (Abdurrahman, 1993:139-140).

Keluargasebagai lingkungan pertama bagi sang anak dalam proses perkembangannya, termasuk bagi proses perkembangan 
moral anak. Keluarga, yang paling tidak terdiri dari orang tua dan anak, harus mampumenjalankan peran dan fungsinya masingmasing dalam proses perkembangan anak, agar anak dapat tumbuh menjadi sosok yang sesuai dengan harapan keluarga dan masyarakat. Menurut Loutzenhiser (Agustina, 2006:17), lingkungan keluarga yang seperti itu dikatakan sebagai family functioning (keberfungsian keluarga). Beberapa ahli pun memiliki penamaan istilah yang berbeda-beda mengenai keberfungsian keluarga itu sendiri, seperti keluarga sehat (healthy family), keluarga fungsional (functional family), keluarga normal (normal family), ataupun keluarga kokoh atau kuat (strong family).

Pada dasarnya, keluarga yang fungsional adalah keluarga yang dapat bekerja dan menjalankan fungsinya dengan baik dan benar (MacArthur, 2000). Senada dengan apa yang didefinisikan oleh Walsh (2003) mengenai keluarga sehat, yaitu suatu kondisi keluarga yang memiliki ciri dan sifat yang ideal yang mana keluarga tersebut dapat menjalankan fungsi secara optimal. Gunarsah mengatakan bahwa orang tua di sini sangat berperan penting dalam perkembangan anak, dan orang tualah yang menjadi faktor utama dalam penanaman nilai-nilai dasar moral anak kelak menginjak dewasa nanti(Fajarwati, 2004:45). Menurut Abdullah Nashih 'Ulwan mengatakan orang tua memiliki banyak tangggung jawab terhadap anak, yaitu ; 1) tanggung jawab pendidikan iman, 2), pendidikan moral/ ahlak, 3) pendidikan fisik, 4) pendidikan fsikis, 5) pendidikan social, 6) pendidikan seks (Ulwan, 2012:112-124).

Keluarga merupakan kesatuan dari orang-orang yang berinteraksi dan berkomunikasi yang menciptakan perananperanan sosial bagi si suami dan isteri, ayah dan ibu, putra dan putri, saudara laki-laki dan perempuan. Peranan-peranan tersebut dibatasi oleh masyarakat, tetapi masing-masing keluarga diperkuat melalui sentimen-sentimen yang sebagian merupakan tradisi dan sebagian lagi persoalan yang menghasilkan pengalaman. Di sinilah keluarga memiliki fungsi besar untuk mengontrol anak, ada beberapa fungsi yang dapat dijalankan 
keluarga, yaitu (1) fungsi biologis (2) fungsi fsikologis (3) sosialisasi (4) fungsi ekonomi (5) fungsi pendidikan, dan (6) fungsi rekretif (Vembrianto, 1993:30).

Dalam pandangan Islam, proses sosialisasi dan penanaman nilai pada diri anak secara praktis dimulai sejak anak dilahirkan.Secara teoretis upaya penanaman nilai-nilai pendidikan sudah dimulai sejak awal pemilihan jodoh. Dalam konteks ini, Nabi Muhammad saw telah memberikan isyarat dengan empat kriteria, yaitu karena kecantikannya, kekayaannya, keturunannya, dan agamanya. Di antara keempat kriteria tersebut, menurut Nabi, untuk terbinanya situasi keluarga sakinah yang bernuansa lslami, hendaklah menjadikan kriteria agama sebagai kriteria utama. Di sisi lain, untuk proses pendidikan pada fase prenatal ini, dianjurkan kepada pasangan suami istri untuk melakukan hubungan dengan sesamanya secara lslami, dan mengawalinya dengan nama Allah, Serta memakan makanan yang halal dan menyehatkan yang sangat menentukan bagi kelangsungan proses perkembangan janin selanjutnya. Pada fase ini anak akan menjadikan perilaku kedua orang tuanya atau keluarganya yang lain, sebagai model dalam perilakunya sehari-hari. Untuk itu, semakin banyak pengalaman yang bernilai agamis mampu ditransfer dan diterimanya, maka akan semakin banyak pula unsur agama dan pengalaman keagamaan yang mampu mewarnai proses pembentukan kepribadiannya. Untuk mengembangkan dimensi kondusif ini, kedua orang tua hendaklah senantiasa berpegang teguh pada nilai-nilai ajaran agamanya.Memandang anak sebagai amanat Allah yang harus dibina sesuai dengan nilai Ilahiah, Serta melaksanakan semua kebijaksanaan sesuai dengan aturan syari'at Islam sebagai hakim dalam kepemimpinannya di lingkungan rumah tangga. Lewat harmonisasi kehidupan yang demikian, anak akan mampu mentauladaninya tanpa terpaksa, akan tetapi secara sadar menjadikan semua kebijaksanaan kedua orang tuanya sebagai acuan moral menjadikan semua kebijaksanaan kedua orang tuanya sebagai acuan moral dalam seluruh aktivitasnya. 
Pada fase ini, anak akan lebih banyak melakukan komunikasi dan interaksi dengan kedua orang tuanya atau anggota keluarganya yang lain, dibanding dengan masyarakat secara makro. Untuk itu, bentuk komunikasi dan interaksi yang dilaksanakan dalam kehidupan keluarganya, akan sangat mempengaruhi bentuk sikap dan perilaku, Serta kepribadian anak selanjutnya. Oleh karena itu, agar proses sosialisasi tersebut berjalan secara edukatif dan sesuai dengan nilai-nilai Ilahiah, maka kedua orang tua harus senantiasa memformulasikan bentuk kehidupan edukatif dan perilaku moral lslami. Dengan sikap ini, akan mampu memberi bekas dan mewarnai sikap serta perilaku anak dalam aktivitas kehidupannya (Ahid, 2010:63). Maka tanggung jawab keluarga menjadi utama, sebagaimana firman Allah SWT "hai orang orang yang beriman, peliharalah dirimu dan keluargamu dan api neraka yang bahan bakarya adalah manusia dan batu, penjaganya malaikat-malaikat yang kasan yang keras, yang tidak mendurhakai Allah terhadap apa yang diperintahkanNya kepada mereka dan selalu mengerjakan apa yang diperintahkan" (Qs. At-Tahrim [66]: 6).

Ali bin Abi Thalib ra. dalam menafsirkan firman Allah SWT

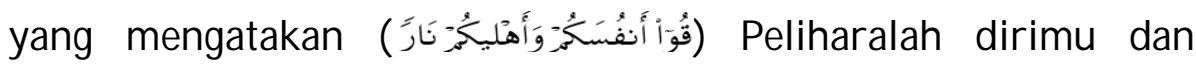
keluargamu dari api neraka mengatakan: علموا أنفسكم و أهليكم خيرا. "Ajarilah diri kalian dan keluarga kalian kebaikan".

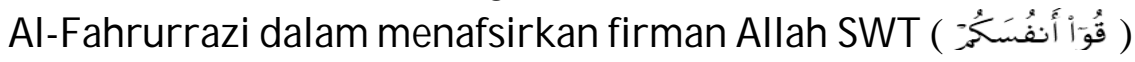
Peliharalah dirimu' mengatakan, 'Yaitu dengan meninggalkan apa yang dilarang Allah atas kalian." Muqatil mengatakan, "Hendaknya seorang Muslim memerintahkan diri dan keluarganya untuk mengerjakan kebaikan dan melarang mereka melakukan

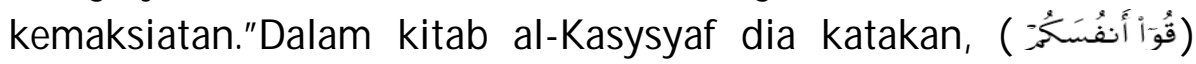
'Peliharalah dirimu' dan meninggalkan kemaksiatan dan mengerjakan ketaatan. Juga untuk keluarga kalian, harus kalian perlakukan sama seperti kalian memperlakukan kalian sendiri (Hafizzh, 2009:49)."

Oleh karena itu, perlu ada usaha dan kerja keras secara terusmenerus dalam mendidik anak, memperbaiki kesalahan mereka 
dan membiasakan mereka mengerjakan kebaikan. lnilah jalan para nabi dan rasul; Nabi Nuh as. mengajak putranya untuk beriman, Nabi Ibrahim as. mengajarkan anaknya untuk beribadah kepada Allah semata, dan demikian seterusnya.

Imam an Nawawi dalam kitab Bustanul Arifin menyebutkau dari asy- Syaffi dari Fudhail mengatakan: Nabi Dawud as. berdoa, wahai Tuhanku, perlakukanlah putraku seperti Engkau memperlakukanku." Maka Allah Swt mewahyukan kepadanya, wahai Dawud, katakanlah kepada putramu agar memperlakukanku sama seperti engkau memperlakukanku, niscaya Aku akan memperlakukannya sama seperti Aku memperlakukanmu. Oleh karena itu, Imam al Ghazali 'rahimahullah dalam risalahnya, Ayyuhal walad, menegaskan bahwa makna pendidikan sama seperti pekerjaan petani yang mencabut duri-duri dan menyiangi rumput-rumput liar, agar tanamannya tumbuh sehat dan mendapat hasil panen yang maksimal. Ibnul Qayyim mengatakan, barang siapa yang dengan sengaja rnengajarkan apa yang bermanfaat bagi anaknya dan meninggalkannya begitu saja, berarti dia telah melakukan suatu kejahatan yang sangat besar. kerusakan pada diri anak kebanyakan datang dari sisi orang tua yang meninggalkan rnereka dan tidak mengajarkan kewajiban-kewajiban dalam agama berikut Sunnah-sunnahnya.

Untuk mendukung terjalinnya proses tersebut, diperlukan keberadaan kehidupan rumah tangga yang harmonis tentram, penuh kedamaian dan kasih sayang, Serta suasana demokrasi yang kondusif dan menjamin kemerdekaanindividu untuk berkembang secara optimal. Tanpa terbinanya suasana kondusiftersebut, maka proses sosialisasi yangdilakukan akan sulit tercapai, sesuai dengan yang diharapkan.

Proses peletakan dasar-dasar pendidikan (basic educational) di lingkungan keluarga, merupakan tonggak awal keberhasilan proses pendidikan selanjutnya, baik secara formal maupun non formal. Demikian pula sebaliknya, kegagalan pendidikan di rumah tangga, akan berdampak cukup besar pada keberhasilan proses 
pendidikan anak selanjutnya. Tentang perkembangan pendidikan anak, Nabi Muhammad SAW bersabda: "Anas ra.mengatakan, bahwa Rasulullah bersabda Anak itu pada hari ketujuh dari kelahirannya hendaklah disembelihkan akikahnya, Serta diberi nama (dengan nama yang baik) dan singkirkan dari berbagai kotoran. Jika ia telah berusia enam tahun, didiklah ia dengan adab susila (akhlak). Jika ia telah berusia 9 tahun hendaklah pisahkan tempat tidumya. Dan jika ia telah berusia 13 tahun, pukullah ia jika tidak mengerjakan shalat. Bila ia telah berusia 16 tahun ia boleh dikawinkan. Setelah itu, ayah berjabatan tangan dengannya dan berkata: Saya telah mendidik, mengajar dan mengawinkan kamu.Untuk itu saya mohon perlindungau kepada Allah dari fitnahan-fitnahan di dunia dan siksaan di akhirat" HR. Muslim (Wahid, 2004:108).

Bila mengacu pada hadits di atas dicermati lebih lanjut, maka akan terlihat dengan jelas peranan dan tanggung jawab kedua orang tua dalam mendidik, mengasuh, dan membina setiap pribadi manusia. Hal ini dapat dimaklumi karena keluarga merupakan lembaga pendidikan pertama dan utama yang dikenal oleh anak. Untuk itu, keberadaan keluarga harus senantiasa memberikan dan mewariskan pengalaman edukatif-ilahiah yang dialogis dan dinamis, sesuai dengan perkembangan tuntunan zamannya. Kondisi ini sangat baik bagi tumbuhnya kepribadian anak secara optimal (Syalabi, 1954:274).

Batasan di atas, memberikan gambaran yang jelas, bahwa hubungan dan tanggung jawab orang tua terhadap keberlangsungan pendidikan anaknya, pada dasarnya tidak bisa dipikulkan kepada orang atau pihak lain. Keberadaan pendidik sebagai tenaga profesional dan keikutsertaan masyarakat dalam membantu proses pendidikan kepada peserta didik, hanya merupakan keikutsertaan mereka dalam membantu orang tua untuk mendidik dan membina anak untuk ke arah tercapainya suatu tujuan yang tertinggi secara optimal. Hal ini disebabkan keterbatasan kemampuan orang tua untuk mendidik anaknya secara sempurna untuk itu ketiga dimensi tersebut harus 
senantiasa saling berkaitan satu dengan yang lain secara harmonis dan integral.

\section{Lingkungan Sekolah}

Lingkungan sekolah merupakan lembaga pendidikan, tempat peserta didik melaksanakan interaksi proses belajar mengajar secara formal (Moeliono, 1990:892). Batasan ini memberikan suatu fenomena, bahwa sekolah merupakan suatu lembaga pelaksana internalisasi nilai-nilai dari suatu kebudayaan, kepada peserta didik secara terarah dan memiliki tujuan. Dalam perspektif pendidikan Islam, setidaknya ada dua hal asasi, yaitu: pertama, tujuan yang jelas, yakni sebagai bentuk pengabdian kepada AllahSWT. Kedua, memiliki kurikulum yang sistematis, dan memuat materi bagi terjadinya proses berpikir dan bertingkah laku yang sesuai dengan nilai-nilai ilahiah, kepada peserta didik.

Walaupun sekolah merupakan sarana transformasi kebudayaan suatu masyarakat, namun eksistensinya tidak seluas kebudayaan secara umum.Eksistensinya hanya merupakan subkultur dari totalitas kebudayaan manusia. Kondisi ini menjadikan sekolah sebagai lembaga yang paling besar peranannya dalam proses dinamika budaya manusia. Hal ini setidaknya disebabkan oleh tiga faktor.Pertama, sekolah merupakan tempat berkumpulnya peserta didik, yang berasal dari berbagai latar belakang kebudayaan yang berbeda.Dalam hal ini, sekolah berfungsi untuk mengakumulasi berbagai bentuk latar belakang kebudayaan peserta didik, dalam suatu bentuk sistem kebudayaaan.Kedua, eksistensi sekolah merupakan miniatur untuk melihat sejauh mana maju mundurya peradaban suatu negara.Ketiga, sekolah merupakan tempat di mana peserta didik menerima berbagai macam bentuk keterampilan yang secara pragmatis dapat diperkirakan dalam kehidupannya, Di pihak lain, sekolah juga merupakan tempat penumbuhan nilai moralitas religius. Dengan nilai tersebut, diharapkan akan mampu menjadi alat control dalam setiap aktivitas yang dilakukannya. 
Dalam hal ini, paling tidak ada delapan fungsi sekolah, yaitu: pertama untuk mempersiapkan anak didik untuk suatu pekerjaan, kedua memberikan keterampilan dasar, ketiga membuka kesempatan memperbaiki nasib, keempat menyediakan tenaga pembangunan, kelima membantu memecahkan masalah sosial, keenam mentransmisi kebudayaan, ketujuh membentuk manusia sosial, dan kedelapan mentransformasi kebudayaan (Nasution, 1995:14-17).

Melihat pendapat di atas, tampak bahwa eksistensi sekolah merupakan sarana yang paling vital dalam proses pemunculan kepribadian manusia seutuhnya. Oleh karena itu, diperlukan suatu sistem yang dialogis, adaptik, dan kondusif bagi optimalisasi pencapaian tugas dan fungsinya,baik secara makro maupun mikro. Secara makro, upaya yang ditempuh adalah dengan menyediakan dan memerhatikan sarana dan prasarana yang dapat menunjang bagi kelancaran proses belajar mengajar secara optimal. Diantaranya adalah letak dan penataan gedung yang cukup strategis dan kondusif bagi suatu proses pendidikan sarana dan prasarana yang mendukung, baik itu peralatan kelas maupun sarana prasarana lainnya, perpustakaan, ruang praktik, rumah ibadah, dan lain sebagainya. Sedangkan secara mikro, upaya yang ditempuh lebih berorientasi pada aspek sistem operasional interaksi proses belajar mengajar, yang meliputi:

Pertama, Kurikulum pendidikan yang integral dan mampu menyentuh seluruh dimensi dan potensi manusia secara utuh, serta bersifat dinamis dan universal. Kedua, Rumusan tujuan pendidikan yang jelas. Ketiga, Proses belajar mengajar yang dialogis dan demokratis.Keempat, tenaga pendidikan yang memiliki kompetensi profesional, baik secara akademik maupun kepribadian,

Menurut Sardiman syarat pendidik meliputi: Persyaratan administratif (kewarganegaraan dan berakhlak baik), Persyaratan teknis (berijazah dan memiliki teknik-teknik keguruan), Persyaratan psikis (sehat rohani, sabar, ramah,sopan, dan 
bertanggung jawab), Persyaratan Fisik (tidak cacat) (Sadirman, 1990:124-125).

Sedangkan menurut Zakiah Daradjat syarat pendidik meliputi: takwa kepada Allah Tuhan Yang Maha Esa, berilmu, Sehat jasmani, berkelakuan baik, mencintaijabatannya, adil, tenang dan sabar, berwibawa, senantiasa gembira, bersifat manusiawi, 1l)bekerja Samadengan sesama guru lainnya, bekerja sama dengan masyarakat.

Menurut Athiyah al-Abrasyi, syarat pendidik meliputi zuhud, bersih jasmani dan rohani dari berbuat tercela, Ikhlas, penyantun, memiliki harga diri, memiliki jiwa pendidik, memahami seluruh karakteristik peserta didik, menguasi dan memahami bidang studi yang diharapkan pendidik akan mampu melaksanakan fungsi dan tugasnya, baik sebagai pengemban tugas profesi, social, agama, maupun pemikul sebagai tanggung jawab orang tua peserta didik.

Jadi tugas pendidik menurut Abdurrahman a-Nawawi, meliputi; penyucian, mengembangkan pembersihan dan menyangkut jiwa anak didik kepada nilai Rabbani, menjauhi semua bentuk kejahatan, dan mejaga agar peserta didik senantiasa berada pada nilai fitrahnya yang hanif, pengajaran, yakni melakukan proses pengalihan berbagai pengetahuan dan akidah kepada akal dan hati anak didik, agar mereka senantiasa mampu merealisasikan dalam setiap aktivitas kehidupan sehari-hari (anNawawi, 1989:171).

\section{Lingkungan Masyarakat}

Masyarakat dapat diartikan sebagi kelompok individu pada suatu komunitas yang terikat oleh suatu kesatuan visi kebudayaan yang mereka sepakati bersama. Setidaknya ada dua macam bentuk masyarakat dalam komunitas kehidupan manusia Pertama, kelompok primer, yaitu kelompok manusia mula-mula berinteraksi dengan orang lain secara langsung, seperti keluarga dan masyarakat secara umum. Kedua, kelompok sekunder, yaitu kelompok yang dibentuk secara sengaja atas pertimbangan dan kebutuhan tertentu, seperti perkumpulan profesi, sekolah, partai 
politik dan sebagainya.Kesatuan ini kemudian membentuk hubungan yang komunikatif dan dinamis, sesuai dengan dinamika tuntutan perkembangan zaman (Muntasir,1985:59).

Jika keterangan di atas, ditarik ke wilayah pendidikan, maka eksistensi masyarakat sangat besar peranan dan pengaruhnya terhadap perkembangan intelektual dan kepribadian individu peserta didik. Sebab, keberadaan masyarakat merupakan laboratorium dan sumber makro yang penuh alternatif di dalam pelaksanaan proses pendidikan (Daradjat, Tahun:45). Untuk itu, setiap anggota masyarakat memiliki peranan dan tanggung jawab moral terhadap terlaksananya proses pendidikan. Untuk itu, pendidikan harus mampu mengakumulasikan seluruh potensi dan nilai kebudayaan masyarakat dan system pendidikannya (Hamid, 1990:80). Dengan upaya kondusif ini, baik masyarakat maupun lembaga pendidikan, akan merasa saling memiliki dan bertanggung jawab atas berhasil atau tidaknya proses pendidikan, dalam mensosialisasikan nilai-nilai kebudayaan dan kemanusiaan.

Sementara itu, Omar Mohammad al-Toumy al-Syaibany berpendapat bahwa masyarakat adalah sebagai tempat dimana individu dan kelompok berinteraksi, menjalin hubungan sesamnya, di mana usaha terpadu, saling memahami dan menyatakan rasa masing-masing.Motivasi dan kebutuhan dapat dipenuhi, masing-masing mempelajari dan menghayati nilai, tradisi, sikap, ciri budaya, dan lain-lain.Semasa berinterkasi inilah idividu dan kelompok perlahan-lahan membina kesatuan sehingga sampai terwujud satu kesatuan ummah dan insan sejagat (alsyaibany,1979:163).

Lebih lanjut al-Syaibany mengemukakan ciri masyarakat menurut Islam, yaitu masyarakat yang dipersatukan oleh kesatuan negara, kebudayaan dan agama, ilmu pengetahun, hak-hak asasi manusia, akidah, perubahan, dan keseimbangan antara dunia dan akhirat, keluarga dan sekolah, jasmani dan rohani, dinamis, kerja keras, pandangan bahwa harta sebagai milik Allah, toleransi, dan akhlak. Selain itu, masyarakat juga harus berpedoman pada 
prinsip kemaslahatan umum, keadilan, persamaan, keseimbangan sosial, jaminan dan setia kawan.

Berbagai hal yang ada di masyarakat itu pada akhirnya megarah pada pemenuhan kehidupan manusia baik yang bersifat fisik maupun non-fisik; materil mapupun spiritual, jasmaniah maupun rohaniah. Semua hal yang ada di masyarakat itu akan dilihat hubungannya dengan pendidikan.

Abdullah Idi, dalam bukunya Sosiologi Pendidikan, Individu, masyarakat dan pendidikan, menjelaskan, bahwa sumbangan atau peran masyarakat terhadap pendidikan adalah sebagai tempat melakukan sosialisasi, kontrol sosial, pelestarian budaya, seleksi pendidikan dan perubahan sosial, serta sebagai lembaga pendidikan (Nata, 2014:60-71).

\section{Masyarakat Sebagai Tempat Sosialisasi}

Sosialisasi atau bermasyarakat merupakan salah satu kemampuan yang harus dimiliki setiap orang. Para peserta didik yang belajar di sekolah, suatu saat akan menjadi anggota masyarakat, karena keberlangsungan hidupnya lebih lanjut berada di masyarakat. Berbagi kebutuhan hidup akan didapati melalui proses interkasi dan komunikasi dengan masyarakat. Sandang, pangan, papan, pasangan hidup (calon istri atau suami) dan lain sebagainya berada di masyarakat.

Dalam proses sosial itu, seorang anak diberikan pemahaman tentang tata cara dan etika bergaul dengan orang lain. Misalnya ketika bertemu mengucapkan salam, bertegur sapa, memberikan salam, menghormari yang lebih tua, menyayangi yang lebih muda, dan menghargai orang yang sebaya, mendatangi undangan jika diundang, menjenguk dan mendoakannya jika sakit, ikut bergembira jika orang lain mendapatkan keberuntungan, ikut simpati dan empati kepada teman yang sedang terkena musibah, mengingatkan atau mencegah orang lain yang akan berbuat sesuatu yang mengganggu kehidupan masyarakat, dengan cara yang bijaksana. 
Pada masyarakat tradisional, berbagai etika dan tata cara bergaul tersebut di atas dituangkan dalam tradisi dan adat istiadat yang dipelihara oleh kaum adat atau pemangku adat; bagi masyarakat modern aturan tersebut dituangkan dalarn bentuk undang-undang, peraturan dan berbagai operating prosedur. Dalam berbagai agama yang diturunkan Tuhan (agama samawi) atau agama yang merupakan buah renungan dan kontemplasi para tokoh spiritual terdapat petunjuk yang lebih dari cukup untuk mengatur jalannya proses sosialisasi, Karena agama dari sejak kelahirannya memiliki komitmen untuk membangun keadaan masyarakat yang tertib, aman dan damai. Agama misalnya mengajarkan tolong menolong, bersaudara dengan sesama manusia, bersikap rendah hati, suka menolong orang lain, berbaik sangka, tidak suka menggunjing orang lain, tidak suka merendahkan atau menghina orang lain, tidak suka memfitnah, suka kerja sama, tidak pendendam, suka berkawan, bemusyawarah, ikhlas dalam membantu orang lain, selalu menciptakan hal-hal yang positif dan menjauhi hal-hal yang mungkar. Perunjuk agama ini akan memberikan kemudahan dan membawa suasana sosialisasi yang produktif dan fungsional. Proses identifikasi, adaptasi, asimilasi, dan integritas yang merupakan bagian dari proses sosialisasi akan terjadi dengan baik, apabila didasarkan pada undang-undaug, peraturan dan nilai-nilai ajaran Islam yang dipatuhi dan dilaksanakan secara konsisten. Islam menganjurkan agar manusia melakukan proses sosialisasi. Misalnya ayat-ayat berikut ini:

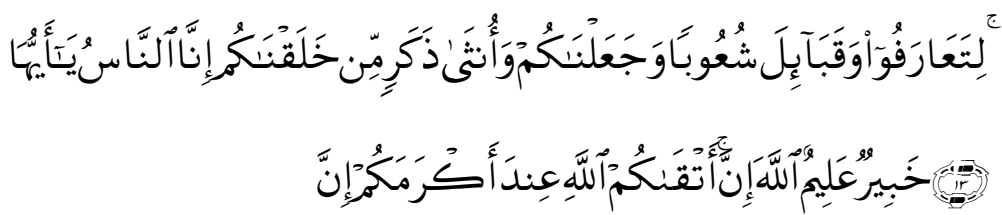

Artinya: "hai manusia, sesungguhnya Kami meciptakan kamu dari seorang laki-laki dan seorang perempuan dan menjadikan kamu berbangsa-bangsa dan bersuku-suku supaya kamu saling kenal-mengenal. Sesungguhnya orang yang paling mulia di 
antara kamu di sisi Allah ialah orang yang puling taqwa di antara kamu.Sesungguhnya Allah Maha Megetahui lagi Maha Mengenal (QSAl-Hujarat [49]: 13).

\section{Masyarakat sebagai Kontrol Sosial}

Masyarakat adalah kumpulan dari sejumlah orang yang tinggal di suatu wilayah, memiliki komitmen, cita-cita dan tujuan yang sama, serta terikat, patuh dan tunduk pada nilai-nilai agama, serta nilaiuilai lain yang disepakati bersama. Setiap anggota masyarakat di samping mendapatkan hak-hak dan jaminan untuk hidup, mengembangkan pendidikan dan berpikir, memilih, menghayati dan mengamalkan agamanya, menentukan bidang usaha ekonominya dan melanjutkan keturunannya, juga memiliki tanggung jawab sosial dan moral (social and moral obligation) yang di dalam ajaran agama disebut sebagai fardlu kifayah (kewajiban kolektif) dan perintah melaksanakan amar ma'ruf nahi mungkar (memerintah orang lain agar berbuat baik dan mencegahnya dari berbuat mungkar). Dengan demikian, masyarakat berperan sebagai kontrol sosial, yakni mengawasi, memantau dan mencegah orang lain berbuat menyimpang. Dalam hubungannya dengan pendidikan, maka masyarakat memiliki peran ikut mengawasi, memantau dan mencegah para pelajar dari kemungkinan melakukan berbagai perbuatan yang merugikan masyarakat. Beredarnya buku, majalah, film dan video porno, peredaran narkoba, premanisme, gank-gank motor, prostitusi, alkohol dan berbagai hal yang dapat memberi pengaruh buruk kepada para pelajar dapat dicegah dengan melibatkan peran serta masyarakat. Kontrol sosial ini mendapatkan perhatian yang besar dalam Islam. Beberapa ayat Al-Quran yang terkait dengan kontrol sosial ini misalnya ayat yang berbunyi:

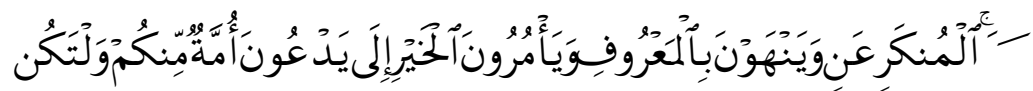

Artinya : Dan hendaknya ada di antara kaum umat yang menyeru kepada kebaikan dan mencegah kemungkaran (QS. Ali 'Imran [3]: 104). 
Ayat tersebut oleh Kuntowijoyo dijadikan dasar untuk mengembangkan konsep ilmu sosial profetik.Yaitu ilmu sosial yang mengemban misi liberasi (pembebasan), humanisasi (memperlakukan manusia dengan baik), dan transendensi (memiliki dimensi ilahiah). Liberasi dimaksudkan bukan memberikan kebebasan sebebas-bebasnya, melainkan membebaskan manusia dari berbagai struktur sosio kultural yang membelenggunya, yang menyebabkan potensinya tidak berkembang sebagaimana mestinya, namun dia tidak dapat berbuat apa saja tanpa memperhatikan ketentuan dari agama. Manusia menjadi terpenjara oleh berbagai hal yang berada di luar dirinya. Akibat dari keadaan yang demikian itu kehidupan mereka menjadi tidak tereksplorasi sebagai mana mestinya, dan mereka berada dalam hegemoni atau penguasaan kekuatan yang berada di luar dirinya. Sedangkan manusiawi dimaksudkan menganggap manusia sebagai saudara yang pada dasamya sama dengan yang Iain. Mereka berasal dari nenek moyang yang sama. Asal usul dan proses kejadian, bahan makanan dan minuman, tempat tinggal, dan lain sebagainya yang sama. Mereka juga masing-masing memiliki kekuatan dan kelemahan, keterbatasan fisik, pancaindra, akal, hati, dan lainnya. Atas dasar pandangan ini, maka manusiawi dipahami, sebagai sikap yang tidak menganggap orang lain lebih rendah dari dirinya, tidak suka mengejek, menghina, merugikan, menipu, berbuat zalim, atau memberikan beban di luar kemampuan dirinya. Manusiawi juga mengandung maksud menghormati, melindungi, menghargai, dan menjamin hak-hak asasi manusia, yaitu hak hidup, hak beragama, hak mengembangkan akal (pendidikan, berpendapat dan berpikir bebas), hak mendapatkan, mengelola dan menggunakan harta benda, serta hak mengembangkan keturunan.

\section{Masyarakat sebagai Pelestarian Budaya}

Budaya sebagaimana dipahami adalah nilai-nilai, ajaran, aturan, atau norma yang tumbuh, hidup dan berkembang di masyarakat 
dan digunakan oleh mereka sebagai acuan, pedoman, dan cognitive framework atau cara pandang yang membingkai pola pikir, pandangan, sikap dan perbuatan. Dengan dernikian, budaya adalah sesuatu yang bersifat batin, jiwa, konsep dan roh yang memengaruhi sesuatu dan sekaligus membedakan antara satu dan lainnya. Budaya orang jawa, orang Sumatera, orang Sunda, Orang Batak, Orang Betawi, dan lain sebagainya berbeda. Karena itu pola pikir, pandangan, sikap dan perbuatan mereka tentang sesuatu masalah masing-masing berbeda-beda. Itulah sebabnya, ketika seseorang akan berkomunikasi, berkunjung, bekerja sama atau membangun sebuah rumah tangga dengan seseorang, maka orang tersebut terlebih dahulu harus saling mengenal. Masa al-ta'arruf (saling mengenal) yang dilakukan oleh seseorang yang akan menjalin kehidupan rumah tangga misalnya, hendaknya jangan digunakan untuk bersenang-senang semata-mata sebagaimana yang umumnya dilakukan oleh orang yang berpacaran. Namun yang lebih panting adalah menggunakan masa al-ta'arruf tersebut untuk saling mengenal, adaptasi, identifikasi, dan asimilasi. Hal ini amat pening dilakukan, agar setelah mereka terikat dalam ikatan perkawinan, mereka akan dapat membangun keluarga yang rukun, damai dan harmonis yang selanjumya disebut sebuah keluarga sakinah.

Tidak hanya itu, budaya juga dapat digunakan sebagai sumber inspirasi, motivasi dan imajinasi dalam menggerakkan sebuah lembaga atau perusahaan. Dalam rangka memajukan perusahaan misalnya, dikehendaki adanya pegawai yang memiliki etos kerja yang tinggi, disiplin, kerja keras, jujur, ramah, santun, kreatif inovanif, cermat, dan tanggung jawab misalnya, maka kepada para pegawai tersebut perlu diberikan nilai-nilai budaya yang dapat mendukung terciptanya pegawai yang demikian. Nilai-nilai budaya tersebut perlu dicari sumbernya, diidentifikasi, dikonstruksi, dirumuskan dan disosialisasikan kepada seluruh pegawainya, sehingga nilai budaya tersebut menjadi cognitive framework mereka. Nilai-niiai budaya tersebut bisa saja digali dari ajaran agama, filsafat hidup, tradisi, norma dan adat-istiadat yang 
tumbuh dan berkembang dalam masyarakat. Nilai-nilai budaya tersebut harus dipelihara dan disinergikan, sehingga tidak menimbulkan apa yang dikenal dengan konflik budaya (class culture).

Dengan demikian, menjadi jelas, bahwa masyarakat adalah merupakan tempat pelestarian nilai budaya. Kerja sama antara sekolah dan masyarakat menjadi penting dilakukan, agar keberadaan masyarakat bersedia menerima kehadiran nilai-nilai yang diajarkan di sekolah dan diberikan kepada para lulusannya yang terjun di masyarakat

\section{Masyarakat sebagi Seleksi Pendidikan}

Diketahui bahwa di masyarakat sebagaimana dikemukakan di atas terdapat berbagai hal yang dibutuhkan lembaga pendidikan, dan sekaligus dapat digunakan sebagai bahan pembelajaran. Masyarakat memiliki sumber daya manusia yang memiliki berbagai keahlian dan profesi seperti : guru, dokter, ahli mesin, budayawan, seniman, pengusaha, pemilik industri, petani yang sukses, tokoh spiritual, dan sebagainya. Di tangan mereka itu terdapat berbagai macam lembaga pendidik, peralatan teknologi, produk seni dan budaya, workshop, pabrik, lahan pertanian, perkebunan, peternakan, perkantoran, bahan makanan, bahan minuman, bahan pakaian, dan masih banyak lagi.Semuanya itu dapat digunakan sebagai tempat melakukan berbagai aktivitas pendidikan. Sekolah dapat memilih dan memanfaatkan apa saja yang ada di masyarakar untuk keperluan pendidikan.

Penggunaan berbagai hal yang ada di masyarakat sebagaimana disebutkan di atas, telah menjadi bahan pemikiran berbagai tokoh pendidikan untuk membangun teori dan konsep pendidikan. John Dewey sebagai pengembang teori belajar progressive misalnya bertitik tolak dari pandangan bahwa ukuran sebuah lembaga pendidikan yang baik, adalah apabila lulusannya dapat berguna dan dibutuhkan masyarakat.Pendidikan yang baik adalah pendidikan yang dapat menghasilkan orang-orang yang dapat hidup di masyarakat.Untuk itu, maka masyarakat tidak lagi dapat 
dilihat sebagai objek pendidikan, melainkan sebagai subjek.Masyarakatlah sesungguhnya yang menjamin hidup matinya masyarakat, Masyarakatlah yang menentukan apakah lembaga pendidikan tersebut terus berlanjut atau harus ditutup.Dalam konteks inilah, masyarakat bertindak sebagai penyeleksi pendidikan.Yaitu memilah dan memilih kembaga pendidikan ymg dapat terus berlanjut dan terpaksa harus berhenti.

\section{Masyarakat sebagai Tempat Belajar}

Di masa sekarang, paradigma pendidikan di samping pemberian informasi baru kepada peserta didik, juga menciptakan keadaan lingkungan berikut sarana prasarana, media, pola pergaulan, kebudayaan dan sebagainya yang memungkinkan peserta didik dapat tumbuh, berkembang dan tereksplorasi segenap potensi yang dimilikinya. Pendidikan tak ubahnya seperti bertani. Lembaga pendidikan (sekolah) ibarat ladangnya, guru ibarat petaninya, peserta didik ibarat bibitnya, perpustakaan, bahan bacaan, media, budaya sekolah, dan lainnya ibarat pupuknya dan keuangan serta administrasinya ibarat airnya. Sebagai ladang, sekolah harus dalam keadaan subur, terbebas dari penyakit.Yakni sekolah tersebut harus menyediakan berbagai hal yang memungkinkan peserta didik sebagai bibit dapat tumbuh dan berkembang dengan subur.Di sekolah tersebut harus terbebas dari pergaulan yang buruk, nilai budaya dan tradisi yang buruk, serta lingkungan yang buruk. Sebagai petani, seorang guru harus dapat memilah dan memilih antara bibit yang unggul dengan bibit yang kurang unggul memiliki kemampuan menanarn bibit tersebut dengan benar dengan tepat; ikut mengontrol dan mengawasi pertumbuhan bibit tersebut jangan sampai kekeringan, hanyut dibawa air terbakar terinjak orang atau tindakan kejahatan lainnya, sehingga bibit yang unggul tersebut dapat tumbuh dengan baik, segar, kokoh, tegak, besar, berdahan, beranting, berdaun, berbunga, dan berbuah. Pohon tersebut menjulang tinggi, menarik untuk dipandang, menjadi tempat berteduh, memelihara 
ekosistem dan lingkungan, tempat penampungan air, menjaga erosi, banjir, dan rnemberikan manfaat lainnya, baik bagi yang menanamnya maupun bagi orang lain yang tidak menanamnya. Ibarat seperti ini mernberikan inspirasi yang amat nyata, bahwa pendidikan di masa sekarang adalah menciptakan keadaan lingkungan sekolah atau masyarakat yang memungkinkan seoralng murid dapat mengembangkan segenap potensi yang dimilikinya, baik fisik, pancaindra, intelektual, sosial, moral (hati nurani) dan spiritualitasnya, atas usahanya sendiri melalui proses interaksi dengan lingkungannya secara produktif.

Dalam konteks pendidikan yang berbasis peserta didik (student centris) dan kreativitas individu ini, maka lingkungan masyarakat peran yang amat strategis.Masyalakat dapat menjadi lahan yang subur bagi tumbuhnya benih yang baik, yaitu peserta didik dengan segala potensi yang dimilikinya. Perumpamaan peserta didik sebagai benih tanaman ini digambarkan dalam A1Qur'an, ketika memberikan sifat dan karakter Nabi Muhammad SAW:

"Muhammad itu adalah utusan Allah. dan orang-orang yang bersamanya adalah keras terhadap orang-orang kafir dan sayang menyayangi di antara sesamanya. Engkau lihat mereka ruku' dan sujud mengharapkan karunia Allah dan keridhaanNya, tanda-tanda mereka ada diwajahnya tampak berkas sujud. Demikianlah perumpamaan mereka (kaum muslim) di dalam Taurat; sedangkan perumpamaannya di dalam Injil, adalah seperti tanaman yang mengeluarkan tunasnya Maka tunas, lalu bertambah kuat dan bertambah besar, tegak lurus pada batangnya, menakjubkan orang-orang yang menanamnya, menjadikan orang-orang kafir marah kepada mereka. Allah telah menjadikan kepada orang-orang yang beriman dan beramal saleh dari mereka ampunan dan pahala yang besar" (QS. AL-Fath, 48: 29).

Pada ayat tersebut Nabi Muhammad diibaratkan seperti tanaman dengan pengertian sebagai berikut. Pertama, sebagai tanaman atau bibit yang unggul yang dipersiapkan Allah Swt. 
untuk menjadi seorang Nabi dan pemimpin umat bahkan pemimpin dunia. Sebagai bibit yang unggul, beliau juga dididik oleh pendidikan yang unggul, yaitu Allah SWT sebagai Maha Guru yang memiliki berbagai sifat kesempurnaan, dan berbagai kesempurnaan lainnya. Pendidikan yang unggul, antara lain harus didukung oleh sumber daya manusia yang unggul, terunama tenaga peendidik, yang dalam hal ini para guru.

Kedua, sebagai sebuah keajaiban tentang keberhasihan yang didasarkan pada perpaduan antara usaha Nabi Muhammad Saw, dengan anugerah Tuhan.Dari sejak dalam kandungan Nabi Muhammad sudah ditinggalkan orang tuanya; umur 6 tahun sudah ditinggalkan oleh Ibunya; kakek dan pamannya juga meninggalkannya, orang-orang yang didekatnya juga meninggalkannya.Lingkungan yang ada di sekitarnya juga cukup keras.Mereka tidak menyukai Nabi Muhammad, bahkam rnembenci, memusuhinya, dan ingin membunuhnya, hingga Nabi Muhammad Saw harus hijrah ke Madinah. Keadaan Nabi Muhammad Saw yang demihan itutak ubahnya seperti tunas sebuah tanaman yang lembut, seperti tunas kelapa. Tunas kelapa yang lembut dapat menembus daging kelapa, kemudian menembus batok kelapa yang keras, menembus kulit kelapa yang tebal, hingga tumbuh dan berkembang menjadi tanaman yang kokoh, tegak (dan memberi manfaat bagi yang menanamnya dan orang lain. Nabi Muhammad Saw yang dalam keadaan lemah itu, namun karena diberikan pendidikan yang baik, maka beliau cepat melaksanakan tugas dengan kesuksesan yang besar dan pengaruh yang amat besar.

Ketiga, sebagai model pendidik yang baik. Di dalam Al-Qu'an Surat AL Jumu'ah (62): 2, Nabi Muhammad Saw memosisikan dirinya sebagai trainer (pelatih), pengajar dan pendidik. Sebagai pelatih ditunjukan oleh potong ayat yatlu "alaikum ayaatihi": menginformasikan tentang ayat-ayat Tuhan. Sebagai pengajar ditunjukkan oleh potongan ayat "wa yu'allimu humul kitaba wa alhikmah": mengajarkan kepada mereka kandungan al-kitab; dan 
sebagai pendidik, ditunjukkan oleh potongan ayat "wu yuzakihim" dan menyucikan dan membersihkan mereka.

\section{Sebagai Lembaga Pendidikan Life Skill}

Pendidikan yang baik, tidak hanya memberikan tuntutan akademik (academic expectation) dengan cara memberikan konsep, teori, dan rumus-rumus tentang berbagai macam ilmu pengetahuan yang muktahir; dan tuntutan masyarakat (social expectation) dengan cara memberikan keterampilan untuk hidup (life skill), baik yang bersifat mental psikologis antara lain dalam bentuk menumbuhkan sikap mental interpreneurship (kewirausahaan), sikap berani mengambil inisiatif dan menanggung resiko, serta mau melakukan sesuatu waupun nilainya kecil namun memiliki posisi yang strategis. Sedangkan yang bersifat praktis vocasional antara lain dengan memberikan keterampilan kerja yang disesuaikan dengan bakat, motivasi, kecenderungan dan harapan yang diinginkan. Misalnya keterampilan menulis, mengoperasikan komputer, menyelenggarakan kegiatan-kegiatan atau cara-cara serimonial (even organizer), berpidato, memasak (kuliner) memperbaiki kendaraan (montir), memotret (fotografer), merias pengantin, merawat kecantikan, membuat obat-obatan tradisional, dan lain sebagainya.

Dengan mengemukakan berbagai catatan sebagaimana tersebut di atas, maka dapat dikatakan, bahwa masyarakat memiliki peranan yang amat besar dalam proses pendidikan dalam arti yang seluas-luasnya, terutama pendidikan nonformal. Masyarakatlah tempat peserta didik menimba berbagai pengalaman yang dapat memperkuat kemampuan kognitif, efektif dan psikomotoriknya; kemampuan fisik, pancaindra, akal pikiran, hati nurani (moral) dan spiritualnya. Masyarakatlah tempat peserta didik mematangkan sikap dan keperibadiannya yang selanjutnya dapat menjadi bekal berharga dalam kehidupannya di masa depan. Untuk mewujudkan keadaan yang demikian, maka diperlukan adanya pendidikan yang berbasis masyarakat.Yaitu 
pendidikan yang menjadikan masyarakat tidak hanya sebagai objek tetapi juga sebagai subjek pendidikan.

\section{KESIMPULAN}

Dalam perspektif Islam, lingkungan pendidikan terdiri dari tiga unsur; keluarga, sekolah dan masyarakat.Ketiga lingkungan tersebut bertanggung jawab atas maju mundurnya pendidikan khususnya pendidikan Islam. Ketiganya merupakan satu kesatuan yang utuh dan saling melengkapi antara yang satu dengan yang lain. Ketiganya harus mampu melaksanakan fungsinya sebagai sarana yang memberikan motivasi, fasilitas edukatif, wahana pengembangan potensi yang ada pada diri peserta didik dan mengarahkannya untuk mampu bernilai efektif-efisien sesuai dengan perkembangan dan kebutuhan zamannya serta memberikan bimbingan dan perhatian yang serius terhadap kebutuhan moral-spiritual peserta didiknya.Untuk itu, di samping ketiga unsur di atas, diperlukan kesiapan dan tanggung jawab yang besar pada diri peserta didik sebagai hamba Allah yang siap melaksanakan amanat-Nya di muka bumi.

\section{DAFTAR PUSTAKA}

Abdullah, T dan Shiddiqi, S. 1989. Tradisi dan KebangkitanIslam di Asia Tenggara, terj. Rochman Achwan. Jakarta: LP3ES

Agustina.2006.Hubungan Antara Keberfungsian Keluarga Dengan Kebermaknaan Hidup Pada Mahasiswa.Skripsi Fakultas Psikologi Universitas Muhammadiyah Surakarta

Ahid, N. 2010.Pendidikan Keluarga Perspektif Islam. Yogyakarta: Pustaka Pelajar

An-Nahlawi, A. 1989.Usus Attarbiyah Al-Islamiyah wa Turuq Tadrisiha. Bandung: Bandung Diponegoro.

An-Nawawi, H. 1989.Organisasi Sekolah dan Pengelolaan Kelas.Jakarta: haji Masagung 
Fajarwati. 2004. Peran Orang Tua Dalam Pendidikan Moral Pada Anak Usia Sekolah 6-12 (th) (Kajian Metori dan Metode). Skripsi Yogyakarta: Fakultas Ilmu Agama Islam Universitas Islam Indonesia.

Hamid, H. A. 1990. Sosiologi Pendidikan dalam Perspektif Pembangunan Negara. Kuala Lumpur: Dewan bahasa dan Pustaka.

MacArthur, J.D. The Functional Family. Utah: Brigham Young University. Mandara, J., dan Murray, C.B. 2002. Development of an Empirical Typology of African American Family Functioning.Journal of Family Psychology. 16 (3) 318-337

Moeliono, A. 1990.Kamus Besar Bahasa Indonesia. Jakarta: Balai Pustaka.

Muntasir, M. S. 1985. Mencari Avidensi Islam,Analisa Sistem Filsafat, Strategi dan Metodelogi Pendidikan Islam.Jakarta: Rajawali Pers.

Nasution. 1995. Sosiologi Pendidikan.Jakarta: Bumi Aksara

Nata, A. 2014.Sosiologi Pendidikan Islam. Jakarta: PT. Raja Grafindo Persada

Sadirman, A. M. 1990. Interaksi dan Motivasi Belajar Mengajar. Jakarta: Rajawali Pers.

St. Vembrianto. Sosiologi Pendidikan. Jakarta: PT. Gramedia Widiasarana Indonesia

Suwaid, M. N. 2009. Prophetic Parenting, Cara Nabi Mendidik Anak. Pro UMedia

Syalabi, A. 1954.Tarikh al-Tauviyat al-Islamiyat. Kairo: Dar alKasysyat

'Ulwan, A. N. 2012. Tarbiyatul Aulad Fil Islam (terj),. Insan Kamil

Walsh, F. 2003. Normal Family Processes, Third Edition : Growing Diversity and Complexity. New York:Guilford Publication. 